\title{
The Right of Privacy and Freedom of the Press: The Concept of Legal Justice in Indonesia
}

\author{
Abdul Haris Nasution \\ Faculty of Law, University of Sumatera Utara, Indonesia. \\ E-mail: haris110860@gmail.com
}

\begin{tabular}{l} 
ARTICLE INFO \\
\hline Keywords: \\
Freedom; Freedom of Press; \\
Privacy Rights \\
How to cite: \\
Nasution, A.H. (2019). "The \\
Right of Privacy and Freedom \\
of the Press: The Concept of \\
Legal Justice in Indonesia," \\
Hasanuddin Law Review, \\
5(1): 77-85 \\
DOI: \\
10.20956/halrev.v5i1.1195
\end{tabular}

\section{Introduction}

After the transition of power from the New Order (Orde Baru) to the Reformation Order in 1998, press freedom in Indonesia began to improve, and all laws and regulations that have impeded press freedom were reevaluated. Law No. 40 of 1999 on the Press has greatly improved the freedom of the press. Those discourses are influenced by the concept of freedom of expression. It is derived from the international human rights instruments that the right to freedom of expression requires not only that everyone is free to express themselves, but that they are free to do so over a range of different types of media, including the print or broadcast media. 
Indeed, Michael Bratton, ${ }^{1}$ has said:

In order to be politically active, citizens require means to communicate with one another and to debate the type of government they desire for themselves. Civic discourse can take place in various forums, the most important of which are the public communications media, both print and electronic.

The concept of press freedom is a contentious one in the literature of mass communication. McQuail, ${ }^{2}$ argues that the concept of media freedom covers both the degree of freedom enjoyed by the media and the degree of freedom and access of citizens to media content. He said that "The essential norm is that media should have a certain independence, sufficient to protect free and open public expression of ideas and information. The second part of the issue raises the question of diversity, a norm that opposes concentration of ownership and monopoly of control, whether on the part of the state or private media industries."

In the last decade, there are often statements that the press in Indonesia is very free at this time, even more free than the press in other democracies. A number of elites even often say that the current media condition has "gone too far" due to being too liberal and free. Former President Megawati Soekarnoputri once conveyed an assessment that the press was now likened to a vehicle whose brakes had not functioned. Although Megawati's concerns were not addressed to all the press and stated that she would not demand a press that was considered excessive, the statement showed some community anxiety about media conditions. ${ }^{3}$

Press freedom contained in Law No. 40/1999 on Press (hereinafter, 'Press Law') has made the press very difficult to touch by law because of the strength of this law protecting the press workers. In fact, a community may be punished for committing a crime if it prevents journalists from carrying out journalistic duties. Meanwhile, if a journalist breaches the law in the case of a report, he shall only be liable to sanctions in the form of granting the right of reply. If one is dissatisfied with the postponement of the right of reply, he may approach the Press Council, a new institution established by the Press Act.

However, with the birth of Press Law, these constitutional rights seem not to be recognised because the regulation of rights in this law only focuses on journalists, and the rights of victims of wrong reporting is only regulated in the right to reply. The legal sanction arrangement for journalists is only a moral sanction of admitting a mistake by simply tendering an apology. The Press Law is regarded as a media and journalist protector, resulting in injustice in the freedom of the press. The liability of the media firm shall only be borne by the responsible person as stipulated in Article 12 of the Press Law; the journalist cannot be touched by law.

Conceptually, there are differences in views regarding how the right of reply mechanism should be implemented in cases involving the press and the public, especially with regard to the right to take a civil lawsuit to court. An opinion is that even if the right of reply is not used, an individual may directly commence a civil suit in court.

1 Bratton, Michael. (1994). Civil Society and Political Transition in Africa. Institute for Development Research Reports, 11(6), 1994, p 2. Available at: http://worlded.org/docs/Publications/idr/pdf/11-6.pdf [accessed 2 January 2017]

2 McQuail, D. (2000). McQuail's mass communication theory. 4th. ed. London: Sage Publications, p. 144-145

3 Nasution, Abdul Haris, Tan Kamello, Budiman Ginting, \& Ningrum Natasya Sirait. (2018). The Paradigm of Justice in Relation to Freedom of the Press and Private Rights. International Journal of Global Community, 1(2), 173-184. http://doi.org/10.5281/zenodo.1323021 
Alternatively, others are of the opinion that the right of reply should be used before a criminal or civil case is instituted if the parties to the conflict could not be resolved by the Press Council. ${ }^{4}$

Therefore, a question which arise at this stage is while performing the aforesaid function, does press enjoy any special right or privilege? The following question: if the Press Law requires no criminalisation of the press, how is the protection of the privacy rights granted in the Civil Code enforced? This study will analyse how legal justice can be obtained by the public regarding privacy rights in relation to the freedom of the press in Indonesia.

\section{The Right to Reply as the First Stage}

In a democracy, freedom of the press is regarded extremely vital and crucial. A freedom of the press is not only a necessary adjunct of democracy, it is the sine qua non for the proper functioning of a democratic society. The primary function of the press in a democratic society is to disseminate correct news and spread the truth. In the many countries, press freedom is not a legal right. The terms 'freedom of the press' are subject to considerable semantic confusion in legal, policy, and theoretical debates. ${ }^{5}$

The freedom of press is basically the freedom of individuals to express themselves through the medium of press. This freedom (of press) is fundamental to the life of an individual in the democratic polity. The concept of free press was explained by William Blackstone long ago in 1769 in the following words:

The liberty of the press, is indeed essential to the nature of a free state; but this consists in laying no previous restraints upon publications and not in freedom from censure for criminal matter when published. Every free man has an undoubted right to lay what sentiments he pleases before the public; to forbid this, is to destroy the freedom of press; but if he publishes what is improper, mischievous, or illegal he must take consequence for his own temerity. To subject the press to the restrictive power of licensor is to subject all freedom of sentiments to the prejudice of one man, and make him the arbitrary and infallible judge of all controverted points in learning, religion, and Government. But to punish any dangerous or offensive writings, which, when published, shall, on a fair and impartial trial, be adjudged of a pernicious tendency, is necessary for the preservation of peace and good order, of Government and religion, the only solid foundation of liberty. ${ }^{6}$

It is widely accepted that the award of damages cannot efficiently restore the harmed reputation. The right of reply can offer a somehow more efficient tool to restore reputation. Initially, the right to reply was only limited to the scope of the code of ethics, but now its existence has also been recognised in the law.

The right of reply could means that if somebody is attacked or defamed in the media that person has the right to have his answer published in the same medium where the original statements were published. The role of the right of reply is to protection for the damaged of someone reputation. The right supports those who are otherwise in a weaker position than those who have the control over the media.

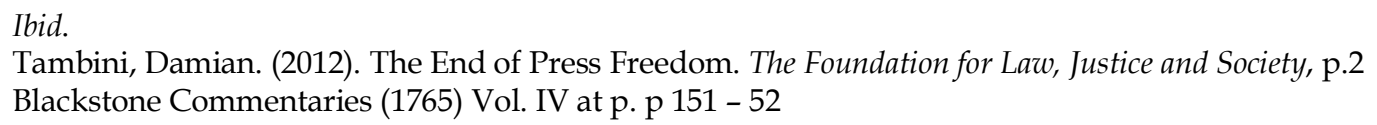


Currently in Indonesia, the right to reply exists both in the Press Law and in the Journalistic Code of Ethics (KEJ) of various Indonesian media organisations. Thus, violation of the right of reply means violating the Press Law and KEJ. In Article 11 of the $\mathrm{KEJ}$, it is stated that Indonesian journalists offer the right of reply and right of correction proportionately. This journalist's right is a follow-up of Article 7 Paragraph 2 of Law No. 40 of 1999 on Press, which states that, "Journalists should have and obey the Code of Ethics of Journalism". This provision has put ethics that was originally a moral obligation into the legal field.

However, with the stipulation of right of reply as the legal norm in positive law, the resolution of a problem according to the ethical norm does not prevent the possibility of legal settlement in accordance with Article 18 Paragraph (2) of the Press Law. Thus, the mechanism of right of reply in the Press Law becomes less effective. Therefore, there is no obligation of the community to make use of the mechanism in question. ${ }^{7}$

The other argument for the right of reply is even more powerful. According to Koltay, ${ }^{8}$ that without any right of reply, it is possible that a false statement is left as the only source of information in the paper in which it was published. The readers should have a chance to gain knowledge of the true facts and the opinion of the person affected. Thereby his knowledge about a particular case can be distorted without the right of reply. The main purpose of reply rights is to guarantee the plurality of opinions published in the press concerning public debates, where the parties have no equal means. It must be admitted that the right to reply is having a democratic character or element. The right of reply is considered to be a channel that carries the expressions or opinions of the public. It guards the balance between the exercise of press freedom and human rights in protecting individuals from possible misuse of the press.

An attempt to use the provisions of the Press Law in solving the problem associated with press coverage is still been debated. On one side, the mistakes in press coverage are resolved through the mechanism of right of reply and right of correction in accordance with the provisions of the Press Law. On the other side, law officers generally tend to apply civil and criminal articles because the arrangements in the Press Law are incomplete. Likewise, several legal considerations of judges indicate that the implementation of right of reply and right of correction does not result in the loss of civil suits and criminal charges. In addition, people often complain that the implementation of the rights of reply is not satisfactory.

The right of reply is important because its use or non-use may determine who wins or loses a court case. Refer to Benny Hermanto case against a weekly media company which had defamed him with the allegation that he sells drugs. The Medan District Court's decision, similar to that of the Medan High Court, pleaded guilty and had to apologized to him. ${ }^{9}$

Judge's decision based on perception of unlawful acts, the claim for compensation on the basis of defamation is regulated in Article 1372 of the Civil Code, which states as follows: "The civil claim of humiliation is aimed at receiving compensation and restitution, honor and reputation". Claims of compensation based on defamation must also comply with the

7 Siregar, R.H. (2006). Mekanisme Penyelesaian Masalah Pemberitaan Pers (Mechanism of Problem Solving Press Reporting). Jakarta: Dewan Pers, p. 83.

8 Koltay, András. 2007. The Right of Reply A Comparative Approach. Iustum Aequum Salutare Iii. 2007/4. p. 203-213. Available At: http://ias.jak.ppke.hu/hir/ias/20074sz/11.pdf. Accessed: July 12, 2018.

9 See Judgment of Medan District Court, No. 228 / Pdt.G / PN-Mdn, dated 24 December 1999 and the decision of the High Court. 176 / PDt / 2002 / PT-MDN, dated July 22, 2002 
requirements of the basic claim of Article 1365, which constitutes a provision governing unlawful acts in general. Thus, the basis of the civil suit under Article 1365 and Article 1372 of the Civil Code are the same, i.e. the existence of unlawful acts which include acts or attitudes that violate the subjective rights of others and violates the legal obligations of the perpetrator himself. The view of this judge was not imprinted in the Press Law. It is a proof of the independence of judges.

Obviously, as the right to reply concept in the Press Law, before the party who feels aggrieved by the press files a civil suit in the court, it must be proved beforehand that the media has indeed denied the right of reply. ${ }^{10}$ The sequence of legal measures proposes must first demand the right of reply from the media organisation. If the right of reply is not granted, the aggrieved party must send the summon up to three times. If the right of reply is still not granted, the aggrieved party may report the case to the police pursuant to violation of Article 5, Paragraph 2 and Article 18 Paragraph 2 of the Press Law. If the court declares that the accused press company violated the criminal provisions, then the party who feels aggrieved may sue to a civil court using article 1365 of the Civil Code.

\section{Legal Justice of Personality Rights in Media}

The mass media is not holy thing. It can violate personality rights in several ways such as the spreading of false information about a person that could negatively impact their reputation, known as defamation. Defamation laws aim to protect the reputations of individuals against injury. So that, some scholars believe that the right to freedom of expression is not absolute and can be a subject to limitations when it infringes upon the personal rights of others.

Everyone has the right to privacy. The goal of privacy laws is to protect people from unwanted intrusions into their private lives. Many civil law jurisdictions also have specific provisions that protect generally private information. The right to privacy is anchored in the Universal Declaration of Human Rights (Article 12):

No one shall be subjected to arbitrary interference with his privacy, family, home or correspondence, nor to attacks upon his honour and reputation. Everyone has the right to the protection of the law against such interference or attacks.

Further discourse is about the exceptions to general privacy rights which can be made when reporting on public figures or when the private information disclosed is in the public interest. According to Warren and Brandeis (1890), as international standards, public officials should tolerate a larger degree of criticism and intrusion into their lives than ordinary citizens. They said that public figures are "individuals who occupy certain prominent positions in society and, therefore, are subject to public interest and scrutiny". Public figure has to tolerate a larger degree of criticism and intrusion than ordinary citizens.

In the words by Nissenbaum, 11 in some contexts, for example, the term "private" indicates the realm of familial and other personal or intimate relations, while the term "public" indicates the civic realm or realm of community outside of this personal one.

10 Parent, W. A. (2017). Privacy, morality, and the law. In Privacy (pp. 105-124). Routledge.

11 Nissenbaum, Helen. 1998. Protecting Privacy in an Information Age: The Problem of Privacy in Public. Law and Philosophy, Vol. 17, No. 5/6 (Nov., 1998), pp. 559-596 Published by: Springer. Available at: http://www.jstor.org/stable/3505189. 
She also argued, that:

In some contexts, "public" indicates the realm of governmental institutions in contrast with the realm of "private" citizens or "private" institutions (such as corporations). In relation to law, the term "private" generally marks a distinctive area dedicated to settling scores between people in their capacities as private citizens, in contrast with "public" law, which generally covers disputes in which officials or agencies of government are involved.

In such cases, the media must be able to prove that the violation of privacy is justified. In the case of Lt. Gen. Djadja Suparman, former Military Commander of Jakarta, 12 reported that during the reforms, he experienced character assassination by the media for alleged involvement in Poso riots, Bali bombing I and corruption. Regarding the first of Bali bombing, Djaja reported six media firms to the Press Council in 2003. The Press Council's decision recommended that the six media firms offer him the right of reply. Although he used the right of reply, Djaja admits that it did not quite improve his name, which has already been reported incorrectly by national and international media. There is a tendency for the press to publish sensational stories that may not be true for financial gain and then later offer the right of reply to the injured party after the damage may have become irreparable. This is described as character assassination by various parties.

That the personality rights shall have protection is a principle as old as the law, but political, social, and economic changes entail the recognition to meet the demands of society. In Indonesia, press freedom has experienced changes based on the government in power. In the days of colonialism, the Dutch East Indies government established Persbreidel-Ordonnantie (persbreidel ordinance) rules to restrict press freedom. The regulation was states that the authorities may at any time act against newspapers and magazines whose contents are considered to disturb public order without opportunity to defend or appeal to a higher court.

After independence, press freedom still suffered the same fate with Law No. 23 of 1954. Restrictions on freedom of the press is a form of media control by the authorities to prevent media practitioners from arbitrarily publishing stories that are perceived to be against the rulers and political or community figures in order to promote Indonesian unity. During the New Order period (1966 - 1998), with Law No. 21 in 1982, the freedom of the press was measured by responsibility and not arbitrariness, so the government protected its citizens from media coverage such as defamation of the rulers and other people.

Post the transition of power from New Order to Reform Order in 1998, freedom of press began to improve, and all laws and regulations that have impeded press freedom were reevaluated. Law No. 40 of 1999 on the Press has greatly improved the freedom of the press. The issuance of a license for publishing news, i.e. the Press Publishing Business License (SIUPP), is no longer valid. Anyone from any circle may publish news through the print media without limitation; the only requirements are that the press companies must be owned by Indonesian citizens or the state itself and must be in the form of an Indonesian legal entity. The new law is deemed not to protect its citizens fairly. The Press Law is more dominant in protecting journalists, to the extent that citizens who are perceived as obstructing the duty of journalists can be sentenced to two years imprisonment or a fine of IDR 500,000,000.

\footnotetext{
12 Nasution, et al. 2018, Op.Cit.
} 
Press freedom contained in Law No. 40/1999 on Press has made the press very difficult to touch by law because of the strength of this law protecting the press workers. In fact, a community may be punished for committing a crime if it prevents journalists from carrying out journalistic duties. Meanwhile, if a journalist breaches the law in the case of a report, he shall only be liable to sanctions in the form of granting the right of reply. If the invasion of privacy constitutes a legal injuria, the elements for demanding redress exist, since already the value of mental suffering, caused by an act wrongful in itself, is recognized as a basis for compensation. It remains to consider what are the limitations of this right to privacy, and what remedies may be granted for the enforcement of the right.

On this issue, there are two main thoughts: First, the right to reply is one of the unique solutions in the press. The use of the right of reply is a compensation given by the press to the parties who feel disadvantaged. If the right of reply has been used, then the press has provided compensation to those who feel that they have been harmed. Thus, through the mechanism of the right to reply, the problem is considered already resolved. Consequently, after the use of the right of reply, the injured party has no right to file a case in court.13

The second thought is that the right of reply given by the law is to satisfy the elements of balance and democracy in the press mechanism. For the sake of order and protection of public interest, the possibility of been compensated in accordance with the general law must remain open to the aggrieved party. If the press has made a mistake, has admitted the mistake, and has given opportunity to the injured party to explain his case through the right to reply, the mistake cannot be automatically erased in disregard to the provisions of the law. In other words, even though the right of reply has been published, it is still possible to prosecute the press through legal means.

This provision can be exercise in the case of humiliation and slander between Tempo Magazine and businessman Tommy Winata in 2003. The decisions of the lower courts were canceled. The Supreme Court in a session led by Chief Justice of the Supreme Court, Bagir Manan, freed the defendant, Chief Editor of Tempo magazine, Bambang Harymurti, because of this right of reply as regulated in Law No. 40 of 1999 on the Press. The Supreme Court is of the opinion that the right of reply was granted by Tempo magazine and that before the news was broadcast by Tempo magazine, it had already been checked by various sources, so the news cannot be categorised as unlawful.

As a result, based on principle of equality before the law, violations of private rights by the media can lead to civil and criminal prosecutions in order to achieve justice. A complaint to the Press Council to use the right of reply is legitimate, but there is no prohibition to prosecute because the court is prohibited from rejecting any case that comes to it in accordance with Article 10 paragraph (1) of Law No. 48 of 2009 on Judicial Power which states as follows: "The court is prohibited from refusing to examine, hear and adjudicate a case filed under the pretext that the law is absent or less clear, but it is obligatory to examine and prosecute". This is further clarified by Article 4 Paragraph (1) which states as follows: "The courts judge according to law by not discriminating against persons". Article 4 Paragraph (2) states that, "Courts help justice seekers and try to overcome all obstacles for the achievement of a simple, fast and just judiciary."

13 Sukardi, Wina Armada. (2007). Keutamaan di Balik Kontroversi Undang-Undang Pers (The Eminence behind the Controversy of Press Law). Dewan Pers, Jakarta, p. 88 
According to John Rawls's theory of justice, ${ }^{14}$ the position of individuals in the society should be the same and equal. According to him, there is no difference in status or position between people. The primal position rests on rationality, freedom and equality to govern the basic structure of society. The position of individuals in the society should be the same and equal. Thus, equality before the law between the public or the individual and the press (journalist) is the same, and nobody is immune from the law. Who does, he is responsible.

\section{Conclusion}

The Indonesian Press Law does not have a clear system of legal liability. The rule of conduct in the Press Law is absolutely not regulated; so, the implementation of the penalty for not granting the right of reply as contained in Article 18 Paragraph (2) of the Press Law is blurred altogether. Thus, the right of reply that is contained in the media consciousness or "order" of the Press Council is not a binding and final decision because the Press Council's body only gives an opinion. Violation of the ethics of the press should not only have a moral sanction but also a legal sanction with all its consequences.

From all these views, it is very clear that in the principle of equality of rights and justice contained in the Press Law has not been seen in law enforcement. Regarding various cases about the press, there are differences in opinions among judges themselves, to the extent of legal uncertainty. Justice is so closely related to rights. However, in the conception of justice in the Indonesian nation, rights cannot be separated from its antinomy partner, namely obligation. Precepts of a just and civilized humanity, for example, firmly mandate harmony between rights and duties as human beings who live in the society. Justice can only be upheld in a civilized society, and, likewise, only civilized society can appreciate justice.

\section{References}

Bratton, Michael. (1994). Civil Society and Political Transition in Africa. Institute for Development Research Reports, 11(6), 1994, p 2. Available at: http://worlded.org/docs/Publications/idr/pdf/11-6.pdf [accessed 2 January 2017]

Koltay, András. 2007. The Right of Reply A Comparative Approach. Iustum Aequum Salutare Iii. 2007/4. p. 203-213. Available At: http://ias.jak.ppke.hu/hir/ias/20074sz/11.pdf. Accessed: July 12, 2018.

McQuail, D. (2000). McQuail's mass communication theory. $4^{\text {th }}$. ed. London: Sage Publications.

Nasution, Abdul Haris, Tan Kamello, Budiman Ginting, \& Ningrum Natasya Sirait. (2018). The Paradigm of Justice in Relation to Freedom of the Press and Private Rights. International Journal of Global Community, 1(2), 173-184. http://doi.org/10.5281/zenodo.1323021

Nissenbaum, Helen. 1998. Protecting Privacy in an Information Age: The Problem of Privacy in Public. Law and Philosophy, Vol. 17, No. 5/6 (Nov., 1998), pp. 559-596 Published by: Springer. Available at: $h t t p: / / w w w . j s t o r . o r g / s t a b l e / 3505189$.

14 Rawls, John. (1971). Theory of Justice. The Belknap Pres of Harvard University Press, Cambridge, Massachusetts. 
Parent, W. A. (2017). Privacy, morality, and the law. In Privacy (pp. 105-124). Routledge.

Rawls, John. (1971). Theory of Justice. The Belknap Pres of Harvard University Press, Cambridge, Massachusetts.

Siregar, R.H. (2006). Mekanisme Penyelesaian Masalah Pemberitaan Pers (Mechanism of Problem Solving Press Reporting). Jakarta: Dewan Pers.

Sukardi, Wina Armada. (2007). Keutamaan di Balik Kontroversi Undang-Undang Pers (The Eminence behind the Controversy of Press Law). Dewan Pers, Jakarta.

Tambini, Damian. (2012). The End of Press Freedom. The Foundation for Law, Justice and Society.

\section{Conflict of Interest Statement:}

The author(s) declares that the research was conducted in the absence of any commercial or financial relationships that could be construed as a potential conflict of interest.

Copyright (C) 2019 HALREV. All rights reserved. 